\title{
Knowledge and attitude among students towards HIV/AIDS patients at a dental college, Suraram, India
}

\author{
Vibha Rani $^{1}$, Suguna Dumpala ${ }^{2 *}$, R. Shyamala ${ }^{3}$
}

${ }^{1}$ Department of Pharmacology,

${ }^{2}$ Department of Community Medicine, ${ }^{3}$ Department of Microbiology, Malla Reddy Medical College for Women, Suraram, Telangana, India

Received: 28 August 2017 Accepted: 25 September 2017

\section{*Correspondence to:}

Dr. Suguna Dumpala,

Email: reachsuguna.dumpala@ gmail.com

Copyright: (C) the author(s), publisher and licensee Medip Academy. This is an openaccess article distributed under the terms of the Creative Commons Attribution NonCommercial License, which permits unrestricted noncommercial use, distribution, and reproduction in any medium, provided the original work is properly cited.

\begin{abstract}
Background: Clinical training is a part of curriculum for the dental students. They are trained in dental procedures, where there is a chance of exposure to HIV infection. Hence this study was conducted with an objective to assess their knowledge, attitude to treat these patients.

Methods: An institutional based study was carried out among 145 dental students at Malla Reddy Dental College for Women. A questionnaire with 29 questions on knowledge, attitude and willing to treat the HIV/AIDS patients which was already used in other study was adapted. Primary outcome- knowledge and attitude was measured in percentages, proportions using SPSS version 20 and Chi-square.

Results: Total subjects who had good knowledge were 71 (48.9\%) and $137(94.5 \%)$ viewed needle stick injury can transmit HIV virus. $138(98.1 \%)$ agreed that it is their moral responsibility to treat HIV/AIDS patients and risk of HIV transmission is high, hence special precautions have to be followed to treat them. Positive attitude towards HIV/AIDS patients was reported among $129(89 \%)$ of students. Chi square test showed an association between knowledge and attitude among study subjects which was statistically significant at $p<0.05$ level.

Conclusions: Active student's collaboration for treatment compliance of HIV/AIDS patients should be directed towards comprehensive training in the dental colleges which forms a basis for provision of appropriate, optimal dental care improving oral health related quality of life in people living with HIV.
\end{abstract}

Keywords: Attitude, Dental students, HIV/AIDS, Knowledge

\section{INTRODUCTION}

Human Immunodeficiency Virus (HIV) is a retrovirus that leads to immune deficiency in humans, now considered as a chronic condition but still remains a serious concern. ${ }^{1}$ Global HIV epidemic in 2016 showed that a total number of $36.7 \mathrm{M}$ people living with HIV/AIDS, out of which adults are $34.5 \mathrm{M}$ (women $17.8 \mathrm{M}$, men $17.7 \mathrm{M}$ ), children $<15 \mathrm{yrs}$ are $2.1 \mathrm{M}$ and $1.8 \mathrm{M}$ people became newly infected with HIV. ${ }^{2}$ The total number of people living with HIV (PLHIV) in India in 2015 is estimated at 21.17 lakhs and undivided Andhra Pradesh and Telangana have the highest estimated number of PLHIV i.e. 3.95 lakhs. $^{3}$ Oral manifestations of HIV infection are a fundamental component of disease progression. They may be in the form of dental caries, hairy leukoplakia, oral candidiasis, necrotizing ulcerative periodontitis, oral ulcers, linear gingival erythema, parotid swelling, Kaposi sarcomas. ${ }^{4,5}$ This special sub-group population seek treatment, which involves oral dental procedures (extractions, orthognathic surgery, periodontal therapy, endodontics, prophylaxis, scaling, root planning and dental implants) as compared with similar patients without HIV/AIDS. Infection can occur during exposure to the blood of an infected patient via needle stick or a splash to exposed mucous membranes. Invasive oral procedures frequently involve contact with saliva and blood that may contain HIV. ${ }^{6,7}$ Those who seek 
dental procedures may be asymptomatic or undiagnosed, so dental health care providers are anxious of getting infected with HIV. Most lesions of HIV/AIDS present orally during the initial stages of the disease, so dentists fall into the high risk category for cross contamination. ${ }^{7} \mathrm{~A}$ major concern among dentists is cross-infection, from an infected patient to the dentist and further from the dentists to other patients in case of an accidental needle stick injury. It is unethical to deny treatment by a dental student or dentist to anyone infected with HIV. ${ }^{8}$ Despite the guidelines by Dental Association of India, ignorance, lack of knowledge on transmission led to refusals to treat HIV/ AIDS patients. ${ }^{9,}{ }^{10}$ The study subjects are the future dentists who will come across PLHV with oral problems. The false beliefs, negative attitude which they might come across during their study period may result in negative impact during their dental practice. There are several studies on knowledge and attitudes of dental students towards HIV/AIDS patients in India but such studies are limited in Telangana state, India. ${ }^{11-13}$ With an increasing number of PLHV, who seek dental care at any given point of time, this study was conducted with an objective to assess knowledge and attitude among students towards HIV/AIDS patients at a dental college.

\section{METHODS}

An institutional based study was conducted to assess knowledge, attitude of students towards PLHV at Malla Reddy Dental College for Women (MRDCW), Suraram, Rangareddy district, Telangana state, which is in the southern part of India. MRDCW has an intake of 100 students every year. The study subjects comprised of II and III year undergraduates dental students. Data was collected on $19^{\text {th }}$ January 2017 . The sample size 168 (88 II year and 80 III year) was calculated based on the number of students on roll. A total of 145 subjects (all women), out of which
70 from II year and 75 from III year participated in the study. Exclusion criteria were: students who were not willing to participate and those who were absent on the day of study. The study subjects were briefed by the principal investigator about the purpose of the study and also took their oral consent. The study was approved by Institutional Ethics Committee. A structured questionnaire was adapted from survey questionnaire used by Patil et al, and Deepak et al, to record the data. ${ }^{12,13}$ It comprised of 29 questions, with two sections. First section of 14 questions was on knowledge of HIV/AIDS, modes of HIV transmission, screening tests, lab diagnosis and oral manifestations. Students were asked to mark answer for each question as Yes/No. Correct answer was given a score of 2 and zero for wrong answer or no response.

The correct responses were summed up, maximum 28 and minimum score was 0 . Study subjects were categorized as follows - score of $>75 \%$ - Excellent, 50-75\% - Good, 25 $50 \%$ - Moderate and $<25 \%$ - Poor knowledge. Second section consisted of 15 questions on attitude and ready to treat HIV/AIDS patients. Attitude response was rated on five point Likerts scale with option of Strongly agree (SA), Agree (A), Neutral, Disagree (D) and Strongly Disagree (SD). The scores were computed from five to one for a positive attitude and inversely from one to five for negative attitude. Attitude was then categorized as score of $\geq 75 \%$ positive, $<75 \%$ - negative. The questionnaire was administered at a time to all study subjects to avoid bias. The primary out-come in this present analysis was knowledge and attitude. A Chi-square test was done to compare overall knowledge and attitude. All statistical analysis was performed using Statistical package for Social Sciences (SPSS Inc, Chicago and III) $20^{\text {th }}$ version. $\mathrm{P}<0.05$ was considered as significant.

\section{RESULTS}

Table 1: Distribution of study subjects by knowledge and awareness on HIV/AIDS.

\begin{tabular}{|llll|}
\hline S. no. & Question & \multicolumn{2}{c|}{ Correct response } \\
\hline 1. & HIV infection can spread by touching, kissing, sharing food and drinks & Number & \multicolumn{1}{c|}{} \\
\hline 2. & Saliva can be a vehicle for transmission of HIV infection & 126 & 86.9 \\
\hline 3. & HIV/AIDS patients can be identified by physical appearance & 78 & 53.8 \\
\hline 4. & Needle stick injury can transmit HIV virus & 119 & 82 \\
\hline 5. & Aerosols from hand pieces can be a vehicle for transmission of HIV infection & 68 & 94.5 \\
\hline 6. & ELISA test is screening test for HIV infection & 134 & 46.9 \\
\hline 7. & Western blot test is a confirmative test for HIV infection & 108 & 72.4 \\
\hline 8. & A negative ELISA test rules out HIV infection & 107 & 73.5 \\
\hline 9. & Medical and paramedical staff is more prone for HIV infection & 86 & 59.3 \\
\hline 10. & Treatment of HIV/AIDS patients requires special dental clinics & 100 & 69 \\
\hline 11. & HIV/AIDS patients can be suspected from oral manifestations & 98 & 67.6 \\
\hline 12. & HIV/AIDS patients can contaminate dental workers & 89 & 61.4 \\
\hline 13. & Dentists can act as an intermediary for transmission of HIV & 90 & 62.1 \\
\hline 14. & Now, AIDS is the most important health problem in the world & 136 & 93.8 \\
\hline
\end{tabular}


As shown in Table 1, 137 (94.5\%) of subjects had the knowledge and awareness on transmission of HIV through needle stick injury, which got the highest score followed by $136(93.8 \%)$ on AIDS as an important health problem in the world, next $134(92.4 \%)$ knew ELISA test is a screening test, $126(86.9 \%)$ answered correctly the first question about spread of HIV by touching, kissing, sharing food and drinks, $119(82 \%)$ said correctly about identification of HIV/AIDS by physical appearance. For questions $2,5,7,8,9,10,11,12$ and 13 , the range of responses was from 68 to 108 (46.9\% to $74.5 \%$ ). However the lowest correct response was Q.5 - for aerosols from hand pieces be a vehicle for transmission of HIV infection (46.9\%).

Table 2 presents total knowledge score among second and third year dental students. Majority $51(68 \%)$ of $3^{\text {rd }}$ year students against $17(24.2 \%)$ of $2^{\text {nd }}$ years had an excellent knowledge of $\geq 75 \%$, while majority of $2^{\text {nd }}$ year students
$47(67.1 \%)$ against $24(32 \%)$ of $3^{\text {rd }}$ year had good knowledge, only $6(8.5 \%)$ of $2^{\text {nd }}$ years had moderate against zero from $3^{\text {rd }}$ year students. While none of them were in weak category. While looking at total knowledge together for both $2^{\text {nd }}$ and $3^{\text {rd }}$ yrs, good $71(48.9 \%)$ was maximum, followed by $68(46.8 \%)$ excellent and $6(4.1 \%)$ moderate.

Table 2: Distribution of study subjects by total knowledge score.

\begin{tabular}{|llll|}
$\begin{array}{l}\text { Knowledge } \\
\text { category }\end{array}$ & $\begin{array}{l}\text { Second } \\
\text { BDS }\end{array}$ & $\begin{array}{l}\text { Third } \\
\text { BDS }\end{array}$ & $\begin{array}{l}\text { Total } \\
\text { knowledge } \\
\text { score N }(\%)\end{array}$ \\
\hline Excellent & $17(24.2)$ & $51(68)$ & $68(46.8 \%)$ \\
\hline Good & $47(67.1)$ & $24(32)$ & $71(48.9 \%)$ \\
\hline Moderate & $6(8.5)$ & 0 & $6(4.1 \%)$ \\
\hline Weak & 0 & 0 & 0 \\
\hline
\end{tabular}

Table 3: Distribution of study subjects by attitude and willingness to treat HIV/AIDS patients.

\begin{tabular}{|c|c|c|c|c|c|}
\hline Question & SA [N (\%)] & $\mathbf{A}[\mathbf{N}(\%)]$ & $\mathbf{N}[\mathbf{N}(\%)]$ & $\mathbf{D}[\mathbf{N}(\%)]$ & SD $[\mathbf{N}(\%)]$ \\
\hline $\begin{array}{l}\text { It is my moral responsibility to treat } \\
\text { HIV/AIDS patient }\end{array}$ & $99(68.3)$ & 39 (26.9) & $2(1.4)$ & $4(2.8)$ & $1(0.7)$ \\
\hline One can safely treat HIV/AIDS patients & $68(46.9)$ & $47(32.4)$ & $24(16.6)$ & $5(3.4)$ & $1(0.7)$ \\
\hline I will treat HIV/AIDS patients & $82(56.6)$ & $46(31.7)$ & $15(10.3)$ & - & $2(1.4)$ \\
\hline $\begin{array}{l}\text { Risk of HIV contagion is high, hence special } \\
\text { precautions have to be followed to treat } \\
\text { HIV/AIDS patients }\end{array}$ & $100(69)$ & $38(26.2)$ & $5(3.4)$ & $1(0.7)$ & $1(0.7)$ \\
\hline Patients with HIV infection can lead a normal & $65(44.8)$ & $52(35.9)$ & $14(9.7)$ & $11(7.6)$ & $3(2.1)$ \\
\hline $\begin{array}{l}\text { Patient's status of HIV infection should be } \\
\text { disclosed to all the family members of the } \\
\text { patient }\end{array}$ & $46(31.7)$ & $42(29)$ & $18(12.4)$ & 17(11.7) & $22(15.2)$ \\
\hline $\begin{array}{l}\text { All dental patients should be considered as } \\
\text { potentially infectious }\end{array}$ & $58(40)$ & $28(19.3)$ & $8(5.5)$ & $37(25.5)$ & $14(9.7)$ \\
\hline $\begin{array}{l}\text { If I know my friend has HIV infection, I will } \\
\text { end the relationship }\end{array}$ & $3(2.1)$ & $2(1.4)$ & $4(2.8)$ & 42 (29) & $94(64.8)$ \\
\hline $\begin{array}{l}\text { If my colleague is HIV infected, I will stop } \\
\text { working with him/her }\end{array}$ & $2(1.4)$ & $4(2.8)$ & $4(2.8)$ & 43 (29.7) & $92(63.4)$ \\
\hline $\begin{array}{l}\text { Treatment of HIV/AIDS patients means } \\
\text { wasting national resources }\end{array}$ & $4(2.8)$ & $3(2.1)$ & $4(2.8)$ & $41(28.3)$ & $93(64.1)$ \\
\hline $\begin{array}{l}\text { Supporting HIV/AIDS patients improves } \\
\text { community health }\end{array}$ & 75 (51.7) & $48(33.1)$ & $11(7.6)$ & $9(6.2)$ & $2(1.4)$ \\
\hline $\begin{array}{l}\text { I will deliver emergency care to HIV/AIDS } \\
\text { patients if need arises }\end{array}$ & $73(50.3)$ & $61(42.1)$ & $9(6.2)$ & $2(1.4)$ & - \\
\hline $\begin{array}{l}\text { I worry about being infected with HIV by my } \\
\text { patients }\end{array}$ & $27(18.6)$ & $43(29.7)$ & $32(22.1)$ & $30(20.7)$ & $13(9)$ \\
\hline $\begin{array}{l}\text { It is my right to know if my patients are } \\
\text { infected by HIV }\end{array}$ & $76(52.4)$ & $55(37.9)$ & $7(4.8)$ & $5(3.4)$ & $2(1.4)$ \\
\hline $\begin{array}{l}\text { Dentists with HIV/AIDS should not be } \\
\text { allowed to practice }\end{array}$ & $6(4.1)$ & $11(7.6)$ & $12(8.3)$ & $44(30.3)$ & $72(49.7)$ \\
\hline
\end{tabular}

SA: Strongly Agree A: Agree N: Neutral D: Disagree SD: Strongly Disagree

Table 3 shows attitude and willingness to treat HIV/AIDS patients among the dental students. Out of 15 questions, maximum students 138 (98.1\%) strongly agreed/agreed (SA/A) that it is their moral responsibility to treat 
HIV/AIDS patients and risk of HIV contagion is high, hence special precautions have to be followed to treat them; 134 (92.4\%) SA/A to deliver emergency care; 131 $(90.3 \%)$ considered their right know the HIV status of their patients; $128(88.3 \%)$ said that they will treat them; 123 (84.8\%) SA/A that improvement of community health is linked with supporting them; $117(80.7 \%)$ said that HIV patients can lead a normal life; $115(79.3 \%)$ felt that HIV patients can be safely treated; $88(60.7 \%)$ strongly agreed that their HIV status to be disclosed to family; 136 (93.8\%) strongly disagreed/disagreed (SD/D) that if friend has HIV, will end relationship; 135 (93.1\%) SD/D to stop working with a colleague with HIV infection; $134(92.4 \%)$ SD/D with treating HIV is waste of resources; $116(80 \%)$ SD/D that dentists with HIV/AIDS should not be allowed to practice.

Table 4 shows total attitude score among dental students. $89 \%$ of students showed a positive attitude against $11 \%$ with negative attitude.

Table 4: Distribution of study subjects by total attitude score.

\begin{tabular}{|ll|}
\hline Attitude category & N $(\%)$ \\
\hline Positive & $129(89)$ \\
\hline Negative & $16(11)$ \\
\hline Total & $145(100)$ \\
\hline
\end{tabular}

Table 5 shows the association between overall knowledge and overall attitude which was statistically significant at $\mathrm{p}$ $<0.05$.

Table 5: Association between knowledge and attitude among study subjects.

\begin{tabular}{|c|c|c|c|c|}
\hline & & $\begin{array}{l}\text { Overall } \\
\text { knowledge } \\
<\mathbf{5 0 \%}>\mathbf{5 0 \%}\end{array}$ & Total & $\mathbf{X}^{2}$ \\
\hline \multirow{2}{*}{$\begin{array}{l}\text { Overall } \\
\text { attitude }\end{array}$} & $>75 \%$ & $\begin{array}{ll}7 & 122\end{array}$ & 129 & \multirow{2}{*}{ *17.941 } \\
\hline & $<75 \%$ & 10 & 16 & \\
\hline \multicolumn{2}{|l|}{ Total } & 13132 & \multicolumn{2}{|l|}{145} \\
\hline
\end{tabular}

\section{DISCUSSION}

Overall knowledge and awareness on HIV/AIDS among study subjects ranged from 68 to 137 (46.9\% to $94.5 \%$ ). About 134 (92.4\%) knew ELISA is a screening test, suggesting good knowledge about diagnostics. However the figures are on higher side when compared to study done by Reshma et al, and Sadeghi et al, 98 (67.6\%) of students agreed that HIV/AIDS patients can be suspected from oral manifestations, which is lower in comparison to similar study done by Sadeghi et al, where the response was $95.2 \% .^{14} 137(94.5 \%)$ of students said that transmission of HIV can occur through needle stick injury which are slightly on lower side when compared to studies conducted by Patil et al and Awad et al. ${ }^{12,15}$ About AIDS as an important health problem in the world, $136(93.8 \%)$ responded correctly which was higher in comparing to study conducted by Deepak et al, and Awad et al. ${ }^{13,15}$ However the lowest correct response was for aerosols from hand pieces be a vehicle for transmission of HIV infection was stated by 68 (46.9\%), which is higher when comparing to a study conducted by Awad et al, where the response rate $48.8 \%$. $^{15}$

Around $126(86.9 \%)$ answered correctly the question on spread of HIV by touching, kissing, sharing food and drinks which is similar to studies conducted by Manish et al. ${ }^{16}$ When asked whether saliva can be a vehicle for transmission of HIV infection, 78 (53.8\%) responded correctly, which is similar to a study done by Abhimanyu et al. ${ }^{17}$ While looking at total knowledge together for both $2^{\text {nd }}$ and $3^{\text {rd }}$ years, good $71(48.9 \%)$ was maximum, followed by $68(46.8 \%)$ excellent and $6(4.1 \%)$ moderate. There was dramatic increase in knowledge of $34 \%$ in excellent category in third year group when compared to second year students, which may be due to better teaching, training and clinical exposure in third year.

An encouraging finding where maximum 138 (98.1\%) strongly agreed/agreed (SA/A) that it is their moral responsibility to treat HIV/AIDS patients and risk of HIV transmission is high, hence special precautions have to be followed to treat them is higher in comparison to similar study conducted by Patil et al. ${ }^{12}$ Some questions like if you know your friend has HIV infection, you will end the relationship, if your colleague is HIV infected, you will stop working with him/her and treatment of HIV/AIDS patients means wasting national resources, got a good attitude score of $93.8 \%, 93.1 \%$ and $92.4 \%$ respectively.

Though these attitude scores are encouraging, there are still some number of dental students who still have fear of HIV contagion and AIDS phobia from their friends and colleagues. These findings are higher in comparison to a study done by Deepak et al, where the response was $86.7 \%, 86.2 \%$ and $88.2 \%$ respectively. ${ }^{13}$ Overall $89 \%$ of students showed a positive attitude against $11 \%$ with negative attitude. The finding is similar to studies conducted by Ara et al, Peeran et al, where positive attitude was reported and differs from previous studies done by Azodo et al, and Neeraj et al, were overall negative attitude was reported among students towards HIV/AIDS patients. ${ }^{18-21}$

\section{CONCLUSION}

From the present study, we conclude that overall students have a good knowledge and a positive attitude towards HIV/AIDS patients. Active student's collaboration for treatment compliance of HIV/AIDS patients should be directed towards comprehensive training in the dental colleges which forms a basis for provision of appropriate, optimal dental care improving oral health related quality of life in people living with HIV. 


\section{ACKNOWLEDGEMENTS}

Authors are grateful towards students of $2 \mathrm{~K} 14$ and $2 \mathrm{~K} 15$ batch for participating in this study. Also like to give special thanks to Kusum Ladda of $2 \mathrm{~K} 14$ batch for helping in distributing and collecting the questionnaire.

Funding: No funding sources

Conflict of interest: None declared

Ethical approval: The study was approved by the Institutional Ethics Committee

\section{REFERENCES}

1. Farahani M, Mulinder H, Farahani A, Marlink R. Prevalence and distribution of non-AIDS causes of death among HIV-infected individuals receiving antiretroviral therapy: A systematic review and metaanalysis. Int J of STD AIDS. 2017;28(7):636-50.

2. Global AIDS update -UNAIDS/WHO estimates 2016. Available at www.unaids.org/en/resources/fact-sheet accessed on 18-July-2017

3. India HIV Estimations 2015. National AIDS Control Organisation \& National Institute of Medical Statistics, ICMR, Ministry of Health \& Family Welfare, Govt. of India.

4. Coogan MM, Greenspan JCS, Challacombe SJ. Oral lesions in infection with human immunodeficiency virus. Bull of the World Health Organization. 2005;83(9):700-6.

5. Cohen LA, Romberg E, Grace E. Revisiting the attitudes of dental faculty toward individuals with AIDS. J Dent Edu. 2001;65(3):249-52.

6. Oliveira ER, Narendran S, Falco A. Brazilian dental students knowledge and attitude towards HIV infection. AIDS Care. 2002;14(4):569-76.

7. Erasmus S, Luiters S, Brijlal P. Oral hygiene and dental students knowledge, attitude and behaviour in managing HIV/ AIDS patients. Int J of Dent Hyg. 2005;3(4):213-17.

8. McCarthy GM, Koval JJ, MacDonald JK. Factors associated with refusal to treat HIV-infected patients: the results of a national survey of dentists in Canada. Am J Public Health. 1999;89(4):541-45.

9. Seacat JP, Inglehart MR. Education about treating patients with HIV infections /AIDS: the student perspective. J Dent Educ. 2003;67(6):630-40.

10. Bennett ME, Weyant RJ, Wallisch JM, Green G. Dentists attitudes toward the treatment of HIV positive patients. J Am Dent Assoc. 1995;126(4):509-14.

11. RahmanR, Kumar SMP. Knowledge, attitude, and awareness of dental undergraduate students regarding human immunodeficiency virus/acquired immunodeficiency syndrome patients. Asian J Pharm Clin Res. 2017;10(5):175-80.

12. Patil PB, Sreenivasan V, Goel A. Knowledge of HIV/AIDS and attitude of dental students towards HIV/AIDS patients: A cross-sectional survey. J Educ Ethics Dent. 2011;1(2):59-63.

13. Singhal DK, Charya S, Sharma K. Knowledge and attitude of dental students towards HIV/AIDS patients: A questionnaire survey. JIARM. 2014;2(3):703-11.

14. Sadeghi M, Hakimi H. Iranian dental students knowledge of and attitudes towards HIV/AIDS patients. J Dent Educ. 2009;73(6):740-5.

15. Alsamghan AS. Knowledge and attitude of male dental students toward HIV/AIDS in King Khalid University, Saudi Arabia. Int. J. Public Health Epidemiol. 2012;1(1):1-8.

16. Jain M, Mathur A, Kumar S, Dagli RJ, Prabu D, Kulkarni S. Knowledge and Attitude among Dental students of Udaipur, India towards HIV/AIDS. J Oral Health Comm Dent. 2008;2(2):30-5.

17. Chauhan AS, Hussain MA, Pati S, Nallala S, Mishra J. Knowledge and attitudes related to HIV/AIDS among medical and allied health sciences students. Indian Journal of Community Health. 2011;23(2):968.

18. Ara SA, Ashraf S, Syed Z, Patil B. A survey of human immunodeficiency virus related knowledge and attitude among dental professionals and students. J HIV Hum Reprod. 2014;2(2):56-61.

19. Syed WP, Kumar PGN, Ramalingam KY, Syed Ali P, Jawad NNA, Elhammali, et al. Knowledge and attitudes of libyan dental students about HIV/AIDS infection and HIV positive patients. Dent Med Res. 2015;3(1):8-14.

20. Azodo CC, Ehigiator O, Oboro HO, Ehizele AO, Umoh A, Ezeja EB, et al. Nigerian dental students willingness to treat HIV-positive patients. J Dent Educ. 2010;74(4):446-52.

21. Grover N, Prakash A, Singh S, Singh N, Singh P, Nazeer J. Attitude and knowledge of dental students of National Capital Region regarding HIV and AIDS. J Oral Maxillofac Pathol. 2014;18(1):9-13.

Cite this article as: Rani V, Dumpala S, Shyamala R. Knowledge and attitude among students towards HIV/AIDS patients at a dental college, Suraram, India. Int J Basic Clin Pharmacol 2017;6:2646-50. 